\title{
PENDAMPINGAN PENULISAN KARYA ILMIAH LOMBA APRESIASI BAGI TUTOR DI PUSAT KEGIATAN BELAJAR MASYARAKAT
}

\author{
${ }^{1}$ Daddy Darmawan, ${ }^{2 *}$ Rahmat Syah, ${ }^{3}$ Adi Irvansyah \\ ${ }^{1,3}$ Universitas Negeri Jakarta, Jakarta, Indonesia \\ ${ }^{2}$ STABN Sriwijaya, Tangerang, Banten, Indonesia \\ Email : rahmat29syah@gmail.com
}

Manuskrip: Desember -2021; Ditinjau: Desember -2021; Diterima: Desember -2021; Online: Januari-2022; Diterbitkan: Januari-2022

\begin{abstract}
ABSTRAK
Tujuan kajian ini adalah memberikan gambaran menganai pelaksanaan pendampingan penulisan kaya Ilmiah untuk Tutor PKBM di DKI Jakarta. Kajian ini menggunakan metode evaluatif, model Kirkpatrick yang mengukur dua level yaitu Reaction dan Learning. Pelatihan melibatkan 30 Tutor dengan purposive sampling. Pengumpulan data dilakukan dengan menyebarkan kuesioner diakhir pelatihan. Hasil penelitian menunjukkan tutor PKBM di DKI Jakarta memiliki sikap antusias terhadap pelatihan menulis. Hal tersebut dikarenakan menulis merupakan kebutuhan yang penting untuk memecahkan permasalahan dalam kelas. Selain itu setelah pelatihan diberikan tutor dapat mengembangkan pemahaman terhadap materi penulisan karya ilmiah, kemampuan mengembangkan latar belakang tutor, pemahaman teknik penulisan, kemampuan mengembangkan ide penulisan, keinginan untuk membuat karya, dorongan untuk belajar dan memberikan motivasi kepada tutor untuk berkarya.
\end{abstract}

\section{Kata Kunci: Penulisan, Tutor, Karya Ilmiah}

\section{PENDAHULUAN}

Individu yang menulis dengan baik dipandang sebagai pemikir substantif (Hall \& Ong, 1984). Penulisan karya ilmiah diakui sebagai bentuk pemecahan masalah (Sadiku, 2015). Terlebih lagi penulisan karya ilmiah yang dilakukan oleh pendidik dalam hal ini tutor Pendidikan masyarakat.

Kemampuan menulis karya ilmiah yang baik bukanlah keterampilan yang diperoleh secara alami, menulis karya ilmiah dipelajari melalui seperangkat praktik dalam pengaturan instruksional formal yang cukup panjang (Call et al., 1994). Namun, banyak pendidik yang masih menerapkan pendekatan pengajaran konvensional (Ka-kan-dee \& Kaur, 2015). Di Indonesia, pengajaran menulis merupakan tantangan. Hal ini disebabkan oleh keterbatasan pemahaman pengajar tentang pendekatan menulis; sehingga pengajar cenderung menggunakan strategi yang terbatas (Suriyanti \& Yaacob, 2016).

Dengan memiliki keterampilan menulis karya ilmiah, seseorang Tutor dapat mengungkapkan berbagai gagasannya untuk dibaca oleh masyarakat. Salah satu 
lembaga yang memiliki tanggung jawab dalam keaksaraan dasar dan lanjutan menyediakan kegiatan akademik ilmiah melalui tulisan adalah Pusat Kegiatan Belajar Masyarakat atau yang lebih dikenal dengan PKBM. Selain itu setiap tahunnya PKBM dan PAUD melombakan kegiatan menulis karya ilmiah yang bertujuan untuk meningkatkan kemampuan tutor dalam berkreasi ilmiah melalui tulisan.

Sehingga keterampilan menulis yang harus dikuasai oleh tutor dan peserta didik adalah menulis karya ilmiah. Menulis karya ilmiah berbeda dengan mengarang biasa. Menulis karya ilmiah membutuhkan metode dan teknik penulisan tertentu sehingga hasil tulisannya dapat dipertanggungjawabkan kebenarannya.

Oleh karena itu, tidak semua orang terampil menulis karya tulis ilmiah. Namun, tuntutan pendidikan di zaman yang kompetitif seperti saat ini sangat membutuhkan keterampilan menulis karya tulis ilmiah untuk memecahkan berbagai persoalan dengan tepat (An Nisa, 2018).

Tutor yang terampil dalam menulis karya tulis ilmiah memiliki nilai plus dibanding orang yang tidak menulis karya ilmiah. Nilai plus yang dimaksud adalah orang yang terampil menulis karya tulis ilmiah mereka akan kaya ilmu pengetahuan, wawasan, bahkan finansial. Mereka terbiasa berpikir sistematis, cermat, tidak sembarangan dalam mengidentifikasi dan memecahkan persoalan.

Lebih lanjut ditemukan bahwa kondisi objektif Tutor PKBM selama ini masih didominasi oleh kegiatan mendidik mengajar dan melatih serta belum banyak melakukan kegiatan pengembangan profesi khususnya penulisan karya tulis ilmiah.

Pengembangan motivasi Tutor PKBM diantaranya dilakukan dengan langkahlangkah: (a) melakukan peningkatan pemahaman dan penguasaan penulisan karya tulis ilmiah melalui diklat penulisan karya tulis ilmiah, (b) menggali topik-topik permasalahan yang akan dikembangkan dalam bentuk karya tulis ilmiah, (c) perlunya melakukan pengembangan knowledge sharing forum yang melakukan konsolidasi keilmuan antar Tutor PKBM.

Kajian ini menggambarkan mengenai pelaksanaan pelatihan penulisan karya ilmiah untuk Tutor PKBM, sehingga tutor dapat mengembangkan cara berfikir ilmiah dan kritis dalam memberdayakan peserta didik.

\section{METODE}

Pendekatan yang digunakan pada kajian ini yaitu dengan pendekatan kuantitatif dan menggunakan metode evaluasi Kirkpatrick (Ritonga, 2019), namun dalam penelitian ini hanya mengambil dua dimensi level evaluasi Kirkpatrick. Responden penelitian ini adalah Tutor PKBM di DKI Jakarta yang mengikuti pendampingan dari kegiatan Pengabdian Masyarakat Dosen UNJ dan menggunakan sebanyak 30 orang tutor yang mengikuti pelatihan. Analisis data menggunakan statistik deskriptif dengan melihat skor rerata dari masing-masing dimensi yang diukur (Coolican, 2018). Dimensi evalasi yang diukur dalam kajian ini adalah sebagai berikut: 
Tabel 1. Dimensi dan Indikator purposive sampling dengan responden

\begin{tabular}{l|l} 
Dimensi & Indikator \\
Reaction & $\begin{array}{l}\text { 1. Kemampuan Narsum } \\
\text { 2. Kesesuaian materi }\end{array}$ \\
Learning & $\begin{array}{l}\text { 3. Kepuasan } \\
\text { 1. Kemampuan Penyerapan Materi } \\
\text { 2. Motivasi Belajar }\end{array}$
\end{tabular}

Selanjutnya pemberian skor untuk melihat dengan menggunakan kategori penilaian kategori dari data yang telah dikumpulkan sebagai berikut:

Tabel 2. Kategori Skor Pengukuran

\begin{tabular}{|c|c|}
\hline Skor & Ket. \\
\hline $86>$ & Sangat Baik \\
\hline $76-85$ & Baik \\
\hline $66-75$ & Cukup \\
\hline $56-65$ & Kurang \\
\hline $55<$ & Sangat Kurang \\
\hline
\end{tabular}

Pengkategorian baik, jika rentang kuantitatif maupun secara kualitatif pada pengukuran di atas $75 \%$, cukup untuk rentang pengukuran nilai, skor \& ketercapaian indikator $66-75 \%$ dan kurang jika didapatkan dari sebuah kriteria. pemenuhan kriteria di bawah $56 \%$ baik.

\section{HASIL DAN PEMBAHASAN}

Kajian evaluatif dari hasil pengumpulan data terhadap dua level langkah Kirkpatrick terdiri dari reaksi (reaction) dan hasil belajar (learning) dilakukan dengan membandingkan kriteria dan indikator dengan data-data di lapangan. Adapun kriteria tersebut disusun berdasarkan kriteria kuantitatif dan kualitatif dengan pertimbangan (Arikunto, Suharsimi \& Pendampingan peserta terhadap pelaksanaan kegiatan memiliki tujuannya untuk mengetaui kepuasan peserta diklat terhadap proses pelatihan yang dilakukan dan dikaji dari beberapa aspek, yaitu materi yang diberikan, kemampuan narasumber, kesesuaian materi pelatihan, kepuasan dan reaksi kepuasan yang digambarkan pada tabel berikut;

Tabel 3. Reaksi Peserta Pendampingan

\begin{tabular}{|c|c|c|c|}
\hline \multirow{2}{*}{ Komponen } & Kriteria & Score & Ket. \\
\hline \multirow{3}{*}{ Kemampuan Narasumber } & Kejelasan Penyampaian & 88 & Sangat Baik \\
\cline { 2 - 4 } & Kejelasan Materi & 89 & Sangat Baik \\
\cline { 2 - 4 } Kesesuaian materi pelatihan & Penguasaan Materi & 80 & Baik \\
\hline \multirow{3}{*}{ Kepuasan } & Kesesuaian materi & 76 & Baik \\
\cline { 2 - 4 } & Manfaat dan kegunaan materi & 87 & Sangat Baik \\
\cline { 2 - 4 } & Pelayanan & 72 & Cukup \\
\cline { 2 - 5 } & Kedisiplinan & 84 & Baik \\
\cline { 2 - 5 } & Akomodasi & 70 & Cukup \\
\hline \multicolumn{2}{|c}{ Rata - Rata } & 80,75 & Baik \\
\hline
\end{tabular}


Rata-rata keseluruhan hasil evaluasi reaksi peserta terhadap penyelenggara adalah 80,75. Nilai angka 80,75 menunjukkan pada kategori "Baik" Berdasarkan evaluasi reaksi peserta terhadap pelatihan ini dapat dikatakan puas. Namun ada beberapa catatan yang perlu yang menjadi perhatian lebih lanjut atau belum sesuai dengan harapan peserta yaitu: maksimal. Berdasarkan hasil observasi lapangan diketahui bahwa peserta cukup aktif setiap sesi. Peserta selalu hadir online tepat waktu pada setiap sesi dan mereka aktif dalam mengikuti sesi penyajian materi. Hasil wawancara menunjukkan bahwa peserta pada umumnya cukup antusias dalam mengikuti pelatihan Kemampuan \& Motivasi Peserta merupakan pengukuran mengenai kondisi pembelajaran atau dalam istilah evaluasinya adalah tahap learning evaluation. Peserta pelatihan berdasarkan hasil data yang dikumpulkan memiliki skor rata-rata 80 atau dalam kategori baik. Dapat dikatakan bahwa transferring pengetahuan mengenai penulisan karya ilmiah dalam kategori baik.

\section{Pembahasan Reaksi Peserta Pelatihan}

Pengukuran reaksi peserta pelatihan disebut sebagai customer satisfaction (Aluko \& Shonubi, 2014). Pengukuran tingkat kepuasan peserta terhadap program pelatihan yang diikuti berdasarkan persepsi dan apa yang dirasakan oleh peserta (Satriono, dkk, 2007). Dari hasil penelitian diperoleh bahwa seluruh peserta merasa puas dengan pelatihan yang diselenggarakan oleh penyelnggara. Reaksi yang baik ini juga dipengaruhi oleh tingkat kualitas dari pelaksanaan pelatihan, yang dapat diukur beberapa aspek dalam pelatihan, yang meliputi: kejelasan penyampaian, kejelasan materi, penguasaan materi, kesesuaian materi, manfaat dan kegunaan materi, pelayanan, kedisiplinan, akomodasi.

Dalam penilaian kualitas pelatihan Tutor PKBM menilai bahwa kemampuan pelatih dalam memberikan pelatihan baik, namun pelayanan dan akomodasi yang masih menunjukkan dengan nilai cukup dengan tujuan dari pelatihan. Tetapi selain dari materi yang diberikan sudah sesuai dan adanya dukungan kelengkapan fasilitas pelatihan yang memadai selama pelatihan sehingga pelatihan dapat berjalan dengan lancar.

Peserta pelatihan akan termotivasi apabila proses pelatihan berjalan secara memuaskan bagi peserta yang pada akhirnya akan memunculkan reaksi dari peserta yang menyenangkan. Sebaliknya jika peserta pelatihan tidak termotivasi, maka jalannya pelatihan juga tidak akan memuaskan sehingga memunculkan reaksi dari peserta yang tidak menyenangkan dan tidak termotivasi untuk mengikuti pelatihan selanjutnya. Menurut Ensour et al., (2018) mengatakan bahwa minat, perhatian, dan motivasi peserta sangat penting bagi keberhasilan setiap program pelatihan. Orang belajar lebih baik ketika mereka bereaksi positif terhadap lingkungan belajar. Berdasarkan hal tersebut dapat dikatakan bahwa keberhasilan suatu pelatihan tidak terlepas dari minat, persepsi, perhatian.

\section{Pemahaman Peserta Pelatihan}

Pemahaman atau penyerapan informasi menurut Bloom diartikan sebagai kemampuan menyerap makna dari materi atau materi yang dipelajari. Pemahaman 
menurut Bloom adalah seberapa besar seseorang mampu menerima, menyerap, dan memahami pelajaran yang diberikan pendidik kepada peserta, atau sejauh mana peserta pelatihan dapat memahami apa yang mereka baca, lihat, alami, atau rasakan dan diukur menggunakan evaluasi sumatif dan formatif (Sivaraman \& Krishna, 2015).

Hasil menunjukan pemahaman tutor terhadap materi penulisan karya ilmiah secara keseluruhan dinilai baik. Meskipun demikian pemahaman mengenai teknik penulisan perlu dikembangkan dengan cara mengaplikasikannya. Tutor harus diberikan banyak kesempatan untuk mempraktikkan keterampilan yang telah mereka pelajari dari program pelatihan. Menurut Sari et al (2021)(Sari et al., 2021), tidak memiliki memperaktikan apa yang diajarkan pada pelatihan akan menghambat kemampuan seseorang untuk menerapkan keterampilannya dan memecahkan masalah kehidupan nyata.

Kreativitas seseorang dalam mencari data secara mandiri maupun kelompok melalui observasi langsung dan wawancara memudahkan mereka dalam menulis artikel ilmiah (Cheong et al., 2019). Dalam hal ini tutor merupakan pendidik yang dituntut untuk mengembangkan kemampuan menulisnya. Hasil data observasi, ditemukan bahwa kemampuan menulis tutor meningkat setelah melalui tahapan investigasi atau investigasi, baik secara individu maupun kelompok dalam pendampingan penulisan karya ilmiah. Keterampilan menulis memerlukan alokasi waktu dan langkah-langkah pembelajaran yang dapat memberikan kesempatan kepada tutor untuk menuliskan hasil investigasi dalam bentuk produk tertulis. Tulisan yang baik dihasilkan melalui proses pendampingan dari kerjasama pendamping dan tutor. Dalam proses pembelajaran, tutor berlatih untuk mengamati, merangkum, mempelajari literatur, dan menulis laporan. Tulisan yang dihasilkan Tutor mengacu pada lima aspek yang ditentukan, yaitu (1) aspek isi, (2) organisasi, (3) tata bahasa, (4) pilihan kata, dan (5) ejaan (Cheong et al., 2019). Dengan demikian, peningkatan kemampuan menulis ilmiah dapat dicapai melalui penggunaan model pembelajaran yang berpedoman pada kompetensi tersebut.

\section{KESIMPULAN}

Seorang Tutor layaknya pendidik dan akademisi harus terbiasa menulis artikel dan laporan ilmiah serta mengembangkan kreativitas untuk memecahkan masalah. Penulisan pun beragam, mulai dari artikel ilmiah, artikel panduan praktis, artikel politik, artikel budaya, dan lainnya. Sedangkan untuk artikel terdapat bentuk essay yang berisi tentang analisis suatu fenomena alam atau sosial yang umumnya berisi alternatif pemecahan suatu masalah. Artikel-artikel ilmiah dalam hal ini ditulis yang menyajikan analisis pengetahuan umum guna memperpendek jarak antara akademisi dengan tentang topik yang sama juga dikenal sebagai Tinjauan Ilmiah. Melalui pelatihan menulis tutor dituntut untuk melakukan sebuah penemuan, atau laporan serts merefleksikannya layaknya akademisi atau seorang peneliti. Pelatihan yang diberikan untuk mengembangkan pemahaman terhadap materi penulisan karya ilmiah, kemampuan mengembangkan latar belakang tutor, pemahaman teknik penulisan, kemampuan mengembangkan ide penulisan, 
keinginan untuk membuat karya, dorongan untuk belajar dan memberikan motivasi kepada tutor untuk berkarya.

\section{DAFTAR PUSTAKA}

Aluko, F. R., \& Shonubi, O. K. (2014). Going beyond Kirkpatrick's Training Evaluation Model: The role of workplace factors in distance learning transfer. Africa Education Review. https://doi.org/10.1080/18146627.2014.935007

An Nisa, K. (2018). Problem Based Learning Dalam Meningkatkan Kemampuan Menulis Karya Ilmiah Mahasiswa. Jurnal Petik, 2(1), 24. https://doi.org/10.31980/jpetik.v2i1.63

Arikunto, Suharsimi dan Jabar Abdul, C. S. (2014). Evaluasi Program Pendidikan. In PT bumi aksara.

Call, M. E., Hadley, A. O., \& Rieken, E. (1994). Teaching Language in Context. The Modern Language Journal. https://doi.org/10.2307/329265

Cheong, M., Yammarino, F. J., Dionne, S. D., Spain, S. M., \& Tsai, C. Y. (2019). A review of the effectiveness of empowering leadership. Leadership Quarterly, 30(1). https://doi.org/10.1016/j.leaqua.2018.08.005

Coolican, H. (2018). Research Methods and Statistics in Psychology. In Research Methods and Statistics in Psychology.https://doi.org/10.4324/9781315201009

Ensour, W., Zeglat, D., \& Shrafat, F. (2018). Impact of job satisfaction on training motivation. Problems and Perspectives in Management, 16(3). https://doi.org/10.21511/ppm.16(3).2018.27

Hall, R. A., \& Ong, W. J. (1984). Orality and Literacy: The Technologizing of the Word. Language. https://doi.org/10.2307/414000

Ka-kan-dee, M., \& Kaur, S. (2015). Teaching Strategies Used by Thai EFL Lecturers to Teach Argumentative Writing. Procedia - Social and Behavioral Sciences, 208. https://doi.org/10.1016/j.sbspro.2015.11.191

Ritonga, R. (2019). Penerapan model evaluasi kirkpatrick empat level dalam mengevaluasi program diklat di Balai Besar Penelitian Pertainan (BBPP) Lembang. Jurnal Pendidikan Nonmormal, 14(1).

Sadiku, L. M. (2015). The Importance of Four Skills Reading, Speaking, Writing, Listening in a Lesson Hour. European Journal of Language and Literature. https://doi.org/10.26417/ejls.v1i1.p29-31

Sari, Y. I., Sumarmi, Utomo, D. H., \& Astina, I. K. (2021). The Effect of Problem Based Learning on Problem Solving and Scientific Writing Skills. International Journal of Instruction, 14(2). https://doi.org/10.29333/iji.2021.1422a

Sivaraman, S. I., \& Krishna, D. (2015). Blooms Taxonomy-Application in Exam Papers Assessment. International Journal of Multidisciplinary Sciences and Engineering, 6(9).

Suriyanti, S., \& Yaacob, A. (2016). Exploring teacher strategies in teaching descriptive writing in indonesia. Malaysian Journal of Learning and Instruction, 13(2). https://doi.org/10.32890/mjli2016.13.2.3. 